\title{
Uma equipa inesquecível
}

Raquel Braga*

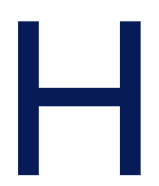

á três anos, abrimos uma nova página ${ }^{1}$ na Revista Portuguesa de Clínica Geral, que hoje, depois de fazermos correr muita tinta, queremos voltar, para poder dar lugar a uma outra página, igualmente promissora e inteiramente em branco, na Revista Portuguesa de Medicina Geral e Familiar.

Mudámos o formato da nossa Revista, mudámos o conteúdo, mudámos de nome, mudámos o processo editorial, procurámos indexação em novas bases de dados. Criámos um site em Open Journal System (OJS), que sendo o repositório de todos os números e artigos desde o ano de 2000, brevemente possibilitará o processo de submissão e de revisão on-line.

Passo a passo, fomos tornando mais célere e refinando o processo editorial, tendo, durante o ano de 2013, chegado a uma demora média de tratamento dos artigos de 53 dias e a uma taxa de aceitação de artigos de $28 \%$.

Como já foi discutido recentemente em outro editorial, ${ }^{2}$ a melhoria da dinâmica do nosso processo editorial sofreu uma evolução que é traduzida através de números expressivos. De uma forma que não é objectivável numericamente, tentámos imprimir uma tónica cada vez mais didáctica, pedagógica e encorajadora ao processo de revisão interpares, dirigindo-o não só à melhoria dos artigos que publicámos, mas também àqueles que tivemos de recusar. Este facto tem sido frequentemente reconhecido através das simpáticas palavras que alguns autores e revisores nos remetem, no final do processo editorial, após verificarem as melhorias expressas pelos seus artigos aquando da publicação.

A nossa equipa de editores dedicou-se de corpo e alma a esta missão e cada um soube dar o seu melhor, por vezes nas piores condições de falta de disponibilidade e de tempo. Todos eles, médicos de família com outras responsabilidades para além da já de si exigen-

*Directora da Revista Portuguesa de Medicina Geral e Familiar te actividade assistencial, fizeram do trabalho editorial um labor diário, tratando os artigos e participando no nosso fórum e no nosso grupo de trabalho e discussão.

No momento da despedida, penso que todos consideramos, unanimemente, que ganhámos tanto ou mais do que o que demos à Revista. Se cada um de nós tinha à partida uma diferenciação distintiva (metodologias de investigação, ética, revisão, sentido critico, aptidão pela escrita, aptidão pelas ferramentas informáticas), no final, todos nos tornámos mais especializados na totalidade das competências editoriais.

Não posso deixar de agradecer nominalmente à Benedita Graça Moura, à Carla Ponte, à Clara Fonseca, ao Daniel Pinto, ao Dilermando Sobral, à Helena Beça, à Inês Rosendo, à Mónica Granja e ao Yonah Yaphe pelo inestimável pedaço das suas vidas quotidianas que empenharam silenciosamente e graciosamente ao serviço da melhoria dos artigos que nos submetem. Não posso também deixar de agradecer à Carla Lopes Mota, ao José Agostinho Santos, ao Miguel Melo e ao Paulo Pires pelo seu empenho e dedicação na secção do Clube de Leitura e dos POEM.

Foi uma longa caminhada na qual já adivinhamos saudades. Este percurso foi deveras vivido, estimulante e intenso, cheio de projectos aprazados e de metas exigentes a cumprir; um trajecto atravessado por algumas vicissitudes, mas coroado com muitas alegrias.

Esta foi, de facto, uma equipa inesquecível!

Não posso também deixar de agradecer ao nosso $p u$ blisher Manuel Magalhães, que sempre nos ofereceu uma atenção e um cuidado inestimáveis, bem como ao nosso revisor técnico Manuel Montenegro e à nossa simpática colaboradora Ana Paula Azevedo, que se ocupou do secretariado.

Juntos fizemos da Revista Portuguesa de Medicina Geral e Familiar uma revista moderna, interessante, rigorosa, que é espelho da investigação produzida em Cuidados de Saúde Primários e que interessa aos Médicos de Família portugueses.

Pensamos que é justo considerar que a Revista se tem também aberto e afirmado como espaço de 
discussão e de opinião acerca das questões de organização e de política de saúde a nível dos Cuidados de Saúde Primários e da sua reforma, bem como da formação médica na nossa especialidade.

Tem-se vindo a gerar um interessante movimento de pensamento a nível dos editoriais, artigos e cartas à Directora, que incentivam à intervenção, ao debate e à opinião e que reflectem uma grande vitalidade editorial, que esperamos que prossiga firmemente.

É este o nosso legado - uma revista funcional, viva e inteligente - à altura e em reflexo da Medicina Geral e Familiar portuguesa.

\section{REFERÊNCIAS BIBLIOGRÁFICAS}

1. Braga R. Uma nova página. Rev Port Clin Geral 2011 Mar-Abr; 27 (2): 137-8.

2. Pinto D. Gestão dos manuscritos submetidos à Revista Portuguesa de Medicina Geral e Familiar nos últimos cinco anos. Rev Port Med Geral Fam 2013 Jul-Ago; 29 (4): 221-3.

\section{CONFLITO DE INTERESSES}

A autora declara ter sido Directora da Revista Portuguesa de Medicina Geral e Familiar durante o triénio de 2011- 2014, tendo desenvolvido uma relação afectiva intensa com a sua equipa editorial e com o projecto de desenvolvimento da Revista.

ENDEREÇO PARA CORRESPONDÊNCIA:

director@rpmgf.pt
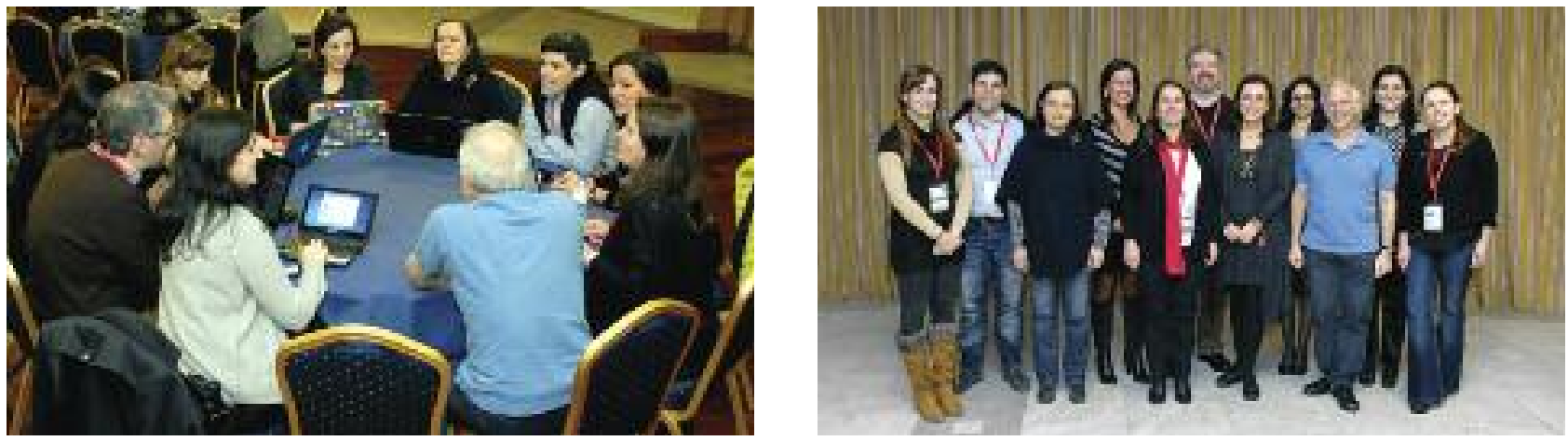

Uma equipa inesquecível 